Pecvnia, 10 (2010), pp. 23-36

\title{
The Relationship Quality Effect on Customer Loyalty
}

Recibido: Mayo 2010 Aceptado: Julio 2010

\author{
Vilte Auruskeviciene \\ vilte.auruskeviciene@ism.lt \\ ISM University of Management and Economics \\ E. Ozeskienes g. 18 \\ Kaunas, LT-44254 Lithuania \\ Laura Salciuviene \\ L.salciuviene@lancaster.ac.uk \\ Lancaster University Management School \\ Department of Marketing \\ Lancaster LA1 4 YX United Kingdom \\ Vida Skudiene \\ vida.skudiene@ism.lt \\ ISM University of Management and Economics \\ E. Ozeskienes g. 18 \\ Kaunas, LT-44254 Lithuania
}

Este estudio tiene como objetivo la identificación de los elementos constitutivos de la calidad de relación que permite a las empresas oferentes de servicios profesionales establecer relaciones a largo plazo con sus clientes y fortalecer la lealtad de los mismos.

El marco teórico sobre el que se ha formulado la identificación de dichos elementos y de la interrelación inherente a la lealtad del cliente ha sido contrastado empíricamente sobre
This study aims to identify the dimensions of relationship quality that enables professional services companies to establish long-term relations with their clients and fosters the loyalty of the client. The theoretical framework of relationship quality dimensions and customer loyalty interrelationship in a sample of 74 Lithuanian companies' managers buying IT service has been empirically tested. The findings suggest that the three variables 
una muestra de 74 directivos de empresas lituanas compradoras de servicios relacionados con las tecnologías de la información. Los resultados sugieren que las variables "calidad funcional", "confianza" y "compromiso" tienen un efecto significativo sobre la lealtad del cliente de servicios de tecnologías de la información. La calidad funcional es el elemento más importante a la hora de construir relaciones a largo plazo con clientes en el mercado de servicios profesionales.

Palabras clave: calidad de relación, lealtad, calidad de servicio, servicios profesionales de tecnologías de la información. (functional quality, trust, and commitment) have a significant effect on IT services customer loyalty. Functional quality construct is the most important in building long-term relationship with customers in a professional services market.

Key words: relationship quality, loyalty, services quality, professional IT services.

\section{INTRODUCCIÓN}

Research in relationship quality reports that more and more firms are capitalizing on strong firm-customer and firm-supplier relationship to gain invaluable information on how best to serve customers and suppliers and keep them from defecting to competing companies (Ndubisi 2004). Gummesson (1987) states that relationship quality has influence on the quality recognized by client, whereas Storbacka, Strandvik and Grönross (1994) postulate that service quality and client satisfaction have positive impact on relationship quality. Crosby, Evans, and Cowles (1990) state that relationship quality is influenced by trust and satisfaction with seller, however Naudé and Buttle (2000) argue that trust, demand, integration and profit have impact on B2B (business-to-business) relationship quality.

The literature on relationship quality suggests that the quality of relationship between the parties involved is an important determinant of loyalty (Leverin and Liljander 2006; Walter, Müller, Helfert and Ritter 2003). Although, there is no consensus regarding the relationship quality dimensions, and little empirical evidence regarding the nature and extent of the overall impact of relationship quality on service quality (Woo and Ennew 2004). This study aims to identify the dimensions of relationship quality that enables professional services companies to establish longterm relations with their clients and fosters the loyalty of the client.

The article begins with the literature review and hypotheses. The methods, results and discussion follow, concluding with the research 
implications and limitations of the study, and suggestions for further research. It is expected that the results of this study would provide a more developed understanding of the role of relationship quality in determining customer loyalty.

\section{THEORETICAL BACKGROUND}

It has been acknowledged that relationship marketing has positive impact on client retention (Sin et al. 2002; Rosenberg and Czepiel 1984; Reichheld and Sasser 1990), however the understanding why customers become loyal still is one of the most crucial (Pritchard, Havitz and Howard 1999). The literature mentions different relationship quality dimensions, however no agreement regarding these has been achieved. The literature review of relationship quality dimensions that positively relate to client loyalty will be provided further.

\section{Communication Effectiveness}

Communication is the basic component of business relationship initiation and development, besides it is a variable that is frequently measured in order to estimate relationship development (Andersen 2001). In the context of relationship marketing, communication implies maintaining relationship with valuable clients, supplying timely and reliable information on services provided or planned changes and alterations of services as well as proactive collaboration when problems occur. The goal of communication is formation of mutual understanding in early phases of relationships, development of client loyalty and encouragement of desired client decisions (Ndubisi and Chan 2005). Clients should feel that company demonstrates genuine interest in the clients themselves as well as in their demands, requirements, value systems and in persuasive way introduce products, services or any other elements of general offer. Furthermore, they should apparently see that company appreciates feedback and makes adequate decisions (Grönroos 2004).

Sharma and Patterson (1999) and Newman, Lings and Lee (2005) state that communication efficiency increases commitment in respect to relationship. This justified Morgan and Hunt (1994) proposition that ensuring easy communication flow is an important feature of strong relationship. Therefore, efficient communication between institution and 
clients determine better relationship and client loyalty (Ndubisi 2007). The following hypothesis is suggested:

\section{H1: Communication effectiveness positively relates to client loyalty}

\section{Trust}

Already in 1983 Berry proposed that the basis of loyalty is trust (Berry 1983). Morgan and Hunt (1994) by the term "trust" mean confiding in partner reliability and honesty. Mitchell, Reast and Lynch (1998) also believe that service provider should be fair and impartial. Callaghan, McPhail and Yau (1995) define trust as credit or conviction in positive intentions of other party in respect to relationship.

The level of trust achieved between partners is an important criterion facilitating evaluation of relationship strength (Ndubisi 2004). Trust mediates satisfaction-commitment link (Ulaga and Eggert 2004). In addition, trust reduces the apprehended by customers risk emerged from transactions and is the main variable towards successful relationship (Boersma, Buckley and Ghauri 2003; Kemp and Ghauri 1998; Morgan and Hunt 1994). On the one hand, establishment of trust and proximity feeling in interpersonal relationships can improve general relationship quality (Wong and Sohal 2002). On the other hand, long-term relationships encourage customer honesty, which motivates both sides to recognize each other better and allows service provider better understand and satisfy client demands, what in turn develops stronger client trust (Czepiel 1990).

The importance of trust in respect to client loyalty was justified by Lim and Razzaque (1997), Garbarino and Johnson (1999), Chaudhuri and Holbrook (2001), Singh and Sirdeshmukh (2000), Morgan, Crutchfield and Lacey (2000), Sirdeshmukh, Singh and Sabol (2002). Therefore, the following hypothesis is suggested:

$\mathrm{H} 2$ : Trust positively relates to client loyalty

\section{Commitment}

Commitment refers to persisting desire to maintain valuable relationship (Moorman, Zaltman and Deshpande 1992; Morgan and Hunt 1994). Commitment emerges as relationship develops gradually and the parties may be committed because of different reasons (Venetis and Ghauri 2004). Morgan et al. (2000) consider commitment one of the two 
most important factors (another factor is trust) determining relationship lasting and approach it as the synonym of customer loyalty. Commitment based on emotions has positive impact on customer intentions (Garbarino and Johnson 1999), on positive verbal communication (White and Schneider 2000; Hennig-Thurau et al. 2002), furthermore, encourages and fosters customer collaboration (Morgan and Hunt 1994) and loyalty (Hennig-Thurau et al. 2002). Therefore, similar as trust, commitment is one of the most significant variables that help to evaluate relationship strength level, and is a useful element of presumable client loyalty measuring. Therefore it is advisable to suggest the following hypothesis:

\section{H3: Commitment towards relationship positively relates to client loyalty}

\section{Social Benefits}

Social involvement refers to the investments of time and energy that determine gradual development of benevolent interpersonal relationship between or among partners, beginning from formal organizational contacts to informal personal (Rao and Perry 2002). Therefore, social involvement is more of personal and not of organizational nature. Venetis and Ghauri (2004) state that thanks to personal contacts information exchange and communications processes between partners are executed in more efficient way, what in general encourages further development of involvement. Wilson (1995) suggests that customers, who have strong interpersonal relationship with suppliers are significantly more involved in maintaining relationship than these [customers], which are related by tenuous social involvement.

Social involvement dimension in the context of relationship market has influence on client loyalty development and enhancement, directly determining the emerging of affection feeling towards the involvement and relationship and, indirectly, that towards organization (Sin et al. 2002). Social benefit includes the conception of amiability and familiarity. Apprehension of these benefits positively relates to such loyalty features as positive word-of-mouth, repeat patronage intentions and client satisfaction with service (Hennig-Thurau et al. 2002; Gwinner, Gremler and Bitner 1998). Thus:

H4: Social benefit positively relates to client loyalty 


\section{Special Treatment Benefits}

The concept of special treatment benefits is defined as better price, bigger discounts, more expeditious provision of a service, rendering of supplementary individualized services, etc. (Gwinner et al. 1998).

According to Alfa.lt portal (2007), corruption factor in Lithuania in 2006 was 4.8. This characterizes Lithuania as high corruption country (authors' note: high factor is considered that up to 5.0). Taking into consideration the specified facts, can be stated that in professional services sector client repeat patronage intentions as well as these to recommend company may be influenced by special treatment benefits, part of which is material encouragement of client representatives, which allows ensuring greater client loyalty.

Though in Hennig-Thurau et al. (2002), Palaima and Auruskeviciene (2007) study the influence of special treatment benefits on client loyalty was not affirmed, however, for the above stated reasons it is advisable to suggest the following hypothesis:

H5: Special treatment benefits positively relate to client loyalty

\section{Technical (TQOS) and Functional Quality of Service (FQOS)}

Service quality includes the two major components: technical quality (basic service or "what" is provided/rendered) and functional quality ("how" a service is provided/rendered) (Grönross 1983; Parasuraman, Zeithaml and Berry 1985). According to Sharma and Patterson (1999), technical and functional quality of service strongly positively relates to trust, and technical quality besides relates to commitment.

The study carried out by Palaima and Auruskeviciene (2007) suggests that service quality affects loyalty. Whereas Woo and Ennew (2004) study does not detect any direct relationship between service quality and client loyalty, however it defined that service quality positively relates to client satisfaction, and this - to client loyalty, which is denominated by the authors as desired behaviour. The following hypotheses are suggested:

H6: Technical quality of service positively relates to client loyalty

H7: Functional quality of service positively relates to client loyalty 
Generalising, the five dimensions of relationship quality, namely, communication efficiency, trust, commitment, social benefits, and special treatment benefits, have been identified based on the literature review.

\section{RESEARCH DESIGN}

\section{Sample And Data Collection}

The hypotheses were verified in professional services market of Lithuania. Invitations to participate in survey were e-mailed to the heads of IT departments at 286 Lithuanian companies, who make decisions or have influence in decision making when choosing the right IT service provider for purchasing services. Invitation e-mail contained hyperlink to interactive online survey.

The survey included few filtering questions:

1. Do you make the decision on what IT service provider should be chosen by your organization? (Yes/No);

2. Do you have influence on the decision on what IT service provider should be chosen by your organization? (Yes/No);

3. Are you in leading position in the IT department? (Yes/No);

To continue the survey, the respondents had to give positive answer ("Yes") at least to one of the questions. Data was not sent to web-based database until all the questions were answered. A total sample of 75 valid responses provided a basis for this study.

\section{Questionnaire Development}

The all constructs were measured on seven-point Likert scale ranging from "Completely disagree" to "Completely agree". The operationalization of constructs is provided in Table 1. 
Table 1: Operationalization of Constructs

\begin{tabular}{|c|c|c|c|}
\hline Code & Variable & Items & Reference \\
\hline \multirow[t]{3}{*}{$\mathrm{CE}$} & \multirow[t]{3}{*}{$\begin{array}{l}\text { Communication } \\
\text { effectiveness }\end{array}$} & $\begin{array}{l}\text { Employee of IT company continuously informs me on the progress } \\
\text { (status) of the projects carried out by him/her in our organization }\end{array}$ & \multirow[t]{3}{*}{$\begin{array}{l}\text { Sharma and Patterson } \\
(1999)\end{array}$} \\
\hline & & Employee of IT company explicitly explains key ideas of the project & \\
\hline & & $\begin{array}{l}\text { Employee of IT company never refuses to provide me the information } \\
\text { to the extent I need to be informed }\end{array}$ & \\
\hline \multirow[t]{6}{*}{ TR } & \multirow[t]{6}{*}{ Trust } & $\begin{array}{l}\text { Employee of IT company keeps to the promises, which he/she gives } \\
\text { to our organization }\end{array}$ & \multirow{6}{*}{$\begin{array}{l}\text { Ulaga and Eggert } \\
\text { (2004); Morgan and } \\
\text { Hunt (1994); Crosby et } \\
\text { al. (1990); Wong and } \\
\text { Sohal (2002) }\end{array}$} \\
\hline & & I believe that IT company considers our best interests & \\
\hline & & I feel that I can always trust this IT company & \\
\hline & & I believe that IT company will do everything correctly & \\
\hline & & Employees of the IT company are honest & \\
\hline & & I feel more confident when I purchase services from this IT company & \\
\hline \multirow[t]{3}{*}{ STB } & \multirow{3}{*}{$\begin{array}{l}\text { Special } \\
\text { treatment } \\
\text { benefits }\end{array}$} & You have higher priority over other clients & \multirow{3}{*}{$\begin{array}{l}\text { Adapted from Hennig- } \\
\text { Thurau } \text { et al. (2002); } \\
\text { Palaima and } \\
\text { Auruskeviciene (2007) }\end{array}$} \\
\hline & & You get better services than other clients & \\
\hline & & You get special discounts or proposals, which other companies don't get & \\
\hline \multirow[t]{4}{*}{ SB } & \multirow{4}{*}{$\begin{array}{l}\text { Social } \\
\text { benefits }\end{array}$} & You are recognized by employees of this IT company & \multirow{4}{*}{$\begin{array}{l}\text { Adapted from Hennig- } \\
\text { Thurau et al. (2002) }\end{array}$} \\
\hline & & You enjoy certain social aspects of the relationship with this IT company & \\
\hline & & You have good relationships with this IT company & \\
\hline & & I know well the employees of this IT company, who provide services & \\
\hline \multirow[t]{4}{*}{$\mathrm{CO}$} & \multirow[t]{4}{*}{ Commitment } & Relationships with IT company are very important to our activities. & \multirow{4}{*}{$\begin{array}{l}\text { Adapted from Ulaga } \\
\text { and Eggert (2004); } \\
\text { Morgan and Hunt } \\
\text { (1994); Hennig-Thurau } \\
\text { et al. (2002); Wong } \\
\text { and Sohal (2002) }\end{array}$} \\
\hline & & $\begin{array}{l}\text { Relationships with this IT company deserve your maximum effort to } \\
\text { maintain. }\end{array}$ & \\
\hline & & $\begin{array}{l}\text { We are going to maintain present relationship with this IT company } \\
\text { for infinite period }\end{array}$ & \\
\hline & & Our relationship with this IT company are as family & \\
\hline \multirow[t]{8}{*}{ TQ } & \multirow{8}{*}{$\begin{array}{l}\text { Technical } \\
\text { quality }\end{array}$} & IT company helps us to implement the best IT technologies & \multirow{8}{*}{$\begin{array}{l}\text { Adapted from Sharma } \\
\text { and Patterson (1999) }\end{array}$} \\
\hline & & IT company performs its projects timely & \\
\hline & & $\begin{array}{l}\text { The projects performed by the IT company ensure smoother } \\
\text { performance of the organization }\end{array}$ & \\
\hline & & $\begin{array}{l}\text { The projects performed by the IT company IT meet contractual } \\
\text { commitments }\end{array}$ & \\
\hline & & $\begin{array}{l}\text { The projects performed by the IT company enabled us to resolve } \\
\text { technical issues that we faced }\end{array}$ & \\
\hline & & It is easy to use the implemented system & \\
\hline & & $\begin{array}{l}\text { Having implemented the system, the amount of its operational faults } \\
\text { is less than anticipated }\end{array}$ & \\
\hline & & $\begin{array}{l}\text { System implementation does not require much efforts of the employees } \\
\text { of the organization }\end{array}$ & \\
\hline \multirow[t]{5}{*}{ FQ } & \multirow{5}{*}{$\begin{array}{l}\text { Functional } \\
\text { quality }\end{array}$} & IT company genuinely cares for the prosperity of our organization & \multirow{5}{*}{$\begin{array}{l}\text { Adapted from Sharma } \\
\text { and Patterson (1999); } \\
\text { Palaima and } \\
\text { Auruskeviciene (2007) }\end{array}$} \\
\hline & & IT company is cooperative in providing services to our organization & \\
\hline & & IT company is amiable in providing services to our organization & \\
\hline & & $\begin{array}{l}\text { IT company promptly reacts to my requests/ questions expressed by } \\
\text { phone }\end{array}$ & \\
\hline & & $\begin{array}{l}\text { IT company promptly reacts to my requests/ questions expressed by } \\
\text { e-mail }\end{array}$ & \\
\hline
\end{tabular}




\begin{tabular}{|c|l|l|l|}
\hline & & $\begin{array}{l}\text { IT company, when providing services, seeks proximately communicate } \\
\text { with the employees of our organization }\end{array}$ & \\
\hline LO & Loyalty & $\begin{array}{l}\text { We hope to expand collaboration scopes with this IT company } \\
\text { We anticipate to implement more projects with this IT company in } \\
\text { the future }\end{array}$ & $\begin{array}{l}\text { Adapted from Sharma } \\
\text { and Patterson (1999); } \\
\text { Palaima and } \\
\text { Most likely in the nearest future we will chose another IT company } \\
\text { Auruskeviciene (2007) }\end{array}$ \\
$\begin{array}{l}\text { A would recommend this IT company to others } \\
\begin{array}{l}\text { If somebody told you that this service provider is bad, you would try } \\
\text { to prove that it is not true }\end{array}\end{array}$ \\
\hline
\end{tabular}

Statistical analysis revealed adequate quality characteristics of all measured constructs. Unit totality (whole correlation) indicators also showed high correlation of the items. This indicates that they can be analysed together. The analysis did not distinguish any additional factors. Therefore it can be stated that all constructs were reliably measured, consequently it is possible to consolidate the data obtained from all questions and for further analysis use their averages.

\section{RESULTS AND DISCUSSION}

Correlations analysis indicated that in significance level 0.01 is relation among all elements of the model (Table 2 ).

Table 2: Verification of Hypothesised Relationships

\begin{tabular}{|c|l|c|c|}
\hline Hypothesis & Relationships & $\begin{array}{c}\text { Pearson } \\
\text { Correlation }\end{array}$ & Support \\
\hline H1 & Communication effectiveness - Loyalty & $.397^{* *}$ & Yes \\
\hline H2 & Trust - Loyalty & $.498^{* *}$ & Yes \\
\hline H3 & Commitment - Loyalty & $.557^{* *}$ & Yes \\
\hline H4 & Social benefits - Loyalty & $.454^{* *}$ & Yes \\
\hline H5 & Special treatment benefits - Loyalty & $.375^{* *}$ & Yes \\
\hline H6 & Technical quality - Loyalty & $.453^{* *}$ & Yes \\
\hline H7 & Functional quality - Loyalty & $.795^{* *}$ & Yes \\
\hline
\end{tabular}

** Correlation is significant at the 0.01 level (2-tailed)

In order to check relationships between pairs of dependant and independent variables linear regression was employed. The defined determination factors are specified in Table 3. Linear regression analysis indicated that the greatest positive impact on client loyalty have trust, commitment and functional quality of services. (determination factor > 0.25). 
Table 3: Determination factors of linear regression

\begin{tabular}{|c|l|c|}
\hline Hypothesis & Relationships & R Square \\
\hline H1 & Communication effectiveness - Loyalty & .158 \\
\hline H2 & Trust - Loyalty & .248 \\
\hline H3 & Commitment - Loyalty & .311 \\
\hline H4 & Social benefits - Loyalty & .206 \\
\hline H5 & Special treatment benefits - Loyalty & .140 \\
\hline H6 & Technical quality - Loyalty & .206 \\
\hline H7 & Functional quality - Loyalty & .632 \\
\hline
\end{tabular}

Since it was expected that all dimensions of relationship quality have positive impact on client loyalty, multiple regression analysis was also carried out. The obtained multiple regression factor was $R=0.812$. Although its value is very high, still it does not mean that all independent variables are important and significant. Using the above specified analysis, the following multiple regression function was calculated:

$$
\begin{array}{cl}
\text { LO_MEAN }= & 0.54 \\
+ & 0.02 \times \text { CE_MEAN } \\
+ & 0.05 \times \text { TR MEAN } \\
+ & 0.23 \times \text { CO MEAN } \\
+ & 0.08 \times \text { SB MEAN } \\
+ & 0.09 \times \text { STB MEAN } \\
+ & 0.02 \times \text { TQ MEAN } \\
+ & 0.68 \times \text { FQ MEAN }
\end{array}
$$

In the obtained multiple regression function are variables with negative values. Having verified empirical and partial correlations between independent variables, it can be seen that independent variables significantly inter-correlate and consequently affect each other distorting factor indications. Virtually it could be possible to attempt to simplify the model trying to find the model with all positive indications and with at least $\geq 0.81$ multiple regression factor, however this would not provide much practical use. All variables are highly interrelated, consequently they should be analysed as a whole. However, as linear regression analysis showed and multiple regressions analysis proved the major impact on loyalty is made by functional quality of service and commitment to relationship.

\section{CONCLUSION}

Our study demonstrated that the three variables (functional quality, trust, and commitment) have a significant impact on IT service 
customer loyalty (business to business segment). Technical quality does not have significant impact on customer loyalty. Furthermore regression analysis revealed that functional quality impact on customer loyalty is more important than trust and commitment dimensions. The most important finding from this empirical study is that functional quality is the most important in building long-term relationship with customers in a professional service market.

Regression analysis revealed the fact that communication effectiveness, social benefits and special treatment benefits almost never positively relates to client loyalty. Regression analysis also revealed the fact that technical quality of a service has no positive impact on client loyalty. Whereas functional quality of service has twice as strong impact on client loyalty if compared with trust and commitment - the relationship dimensions defined by Morgan and Hunt (1994) that by now became almost de facto. It was defined that functional quality of service, which was defined as the synthesis of such qualities common for all humanity as sincerity, helpfulness and amiability and such objective features as prompt reaction and proximate communication basically was the main direct reason for IT service client loyalty.

\section{REFERENCES}

Alfa.lt (2007, June 26) "Korupcijos lygis Lietuvoje nemažejja" [http:// media.ft.com/cms/a48e3432-5807-11dd-b02f-000077b07658.pdf].

ANDERSEN, P.H. (2001) "Relationship Development and Marketing Communication: an Integrative Model", Journal of Business \& Industrial Marketing, 16, 2, pp. 167-182.

BerRY, L.L. (1983) "Relationship Marketing". L.L. BerRY, G.L. SHOSTACK and G.D. UpAH (eds.) Emerging Perspectives on Services Marketing. Chicago: American Marketing Association, pp. 25-28.

Boersma, M.; P. BuCKLEY and P. GHAURI (2003) "Trust in International Joint Venture Relationship", Journal of Business Research, 56, March, pp. 1031-1042.

CALLAGHAN, M.; J. MCPHAIL and O.H.M. YAU (1995) "Dimensions of a Relationship Marketing Orientation: an Empirical Exposition", Proceedings of the Seventh Biannual Word Marketing Congress, 7, 2, pp. 10-65. 
ChaudhuRI, A. and M. HolBRook (2001) "The Chain of Effects from Brand Trust and Brand Effect to Brand Performance: the Role of Brand Loyalty", Journal of Marketing, 65, 2, pp. 81-93.

CROSBY, L.A.; K.R. EVANS and D. COWLES (1990) "Relationship Quality in Services Selling: an Interpersonal Influence Perspective", Journal of Marketing, 54, 3, pp. 68-81.

CzepIeL, J. (1990) "Service Encounters and Service Relationships: Implication for Research", Journal of Business Research, 20, 1, pp. 13-21.

GARBARINO, E. and M. JoHnSON (1999) "The Different Roles of Satisfaction, Trust and Commitment in Customer Relationships", Journal of Marketing, 63, 2, pp. 70-87.

GRÖNRoOS, C. (2004) "The Relationship Marketing Process: Communication, Interaction, Dialogue, Value", Journal of Business \& Industrial Marketing, 19, 2, pp. 99-113.

- (1983) Strategic Management and Marketing in the Service Sector. Cambridge MA: Marketing Science Institute.

GUMmESSON, E. (1987) "The New Marketing: Developing Long-Term Interactive Relationships", Long Range Planning, 20, 4, pp. 10-20.

GWINNER, K.P.; D.D. GREMLER and M.J. BITNER (1998) "Relational Benefits in Services Industries: the Customer's Perspective", Journal of the Academy of Marketing Science, 26, 2, pp. 101-114.

HenNIG-ThuRaU, T.; K.P. GWINER and D.D. GREMLER (2002) "Understanding Relationship Marketing Outcomes: an Integration of Relational Benefits and Relationship Quality", Journal of Service Research, 4, 3, pp. 230247.

KEMP, R. and P.N. GHAURI (1998) "The Dynamics of Joint Venture Relationship: A Longitudinal Perspective of Two Case Studies". A. MANRAI and L. MANRAY (eds.) Research in Marketing. Stamford, Conn.: Jai Press, vol. 14, pp. 123-150.

LeVERIN, A. and V. LILJANDER (2006) "Does Relationship Marketing Improve Customer Relationship Satisfaction and Loyalty?", International Journal of Bank Marketing, 24, 4, pp. 232-251.

LIM, K.S. and M.A. RAZZAQUE (1997) "Brand Loyalty and Situational Effects: an Interactionist perspective", Journal of International Consumer Marketing, 9, 4, pp. 95-115.

MITCHELL, P.; J. REAST and J. LYNCH (1998) "Exploring the Foundations of Trust", Journal of Marketing Management, 14, pp. 159-72. 
MOORMAN, C.M.; G. ZaltMAn and R. DeshPANDE (1992) "Relationship between Providers and Users of Market Research: the Dynamics of Trust within and between Organizations", Journal of Marketing Research, 29, 3, pp. 314-328.

MORGAN, R.; T. CRUTCHFIELD and R. LACEY (2000) "Patronage and Loyalty Strategies: Understanding the Behavioral and Attitudinal Outcomes of Customer Retention Programs". Thorsten HENNIG-THURAU and Ursula HANSEN (eds.) Relationship Marketing, Berlin: Springer, pp. 71-87.

- and S. HUNT (1994) "The Commitment - Trust Theory of Relationship Marketing", Journal of Marketing, 58, pp. 1-38.

NAUDÉ, P. and F. BUTTLE (2000) "Assessing Relationship Quality", Industrial Marketing Management, 29, 4, pp. 351-361.

NDUBISI, N.O. (2004) "Understanding the Salience of Cultural Dimensions on Relationship Marketing, It's Underpinnings and Aftermaths", Cross Cultural Management, 11, 3, pp. 70-89.

- (2007) "Relationship Marketing and Customer Loyalty", Marketing Intelligence \& Planning, 25, 1, pp. 98-106.

- and K.W. CHAN (2005) "Factorial and Discriminant Analyses of the Underpinnings of Relationship Marketing and Customer Satisfaction", International Journal of Bank Marketing, 23, 3, pp. 542-557.

Newman, A.; I. LINGS and N. LeE (2005) "What's in a Handshake? Exploring Business-to-Business Relational Exchange", The Marketing Review, 5, pp. 129-144.

Palaima, T. and V. AuRUSKeviciene (2007) "Modelling Relationship Quality in the Parcel Delivery Services Market", Baltic Journal of Management, 2, 1, pp. 37-54.

Parasuraman, A.; V.A. Zeithaml and L.L. Berry (1985) "A Conceptual Model of Service Quality and its Implications for Future Research", Journal of Marketing, 49, pp. 41-50.

PRITCHARD, M.; M. HAVITZ and D. HowARD (1999) "Analyzing the Commitment Loyalty link in the Service Contexts", Journal of the Academy of Marketing Science, 27, 3, pp. 333-48.

RAO, S. and C. PERRY (2002) "Thinking about Relationship Marketing: Where are we now?", Journal of Business \& Industrial Marketing, 17, 7, pp. 598-614.

REICHHELD, F.F. and W.E. SASSER Jr. (1990) "Zero Defections: Quality Comes to Service", Harvard Business Review, 68, pp. 105-111. 
Rosenberg, L.J. and J.A. CZePIEL (1984) "A Marketing Approach to Customer Retention", Journal of Consumer Marketing, 1, pp. 45-51.

SHARMA, N. and P. PATTERSON (1999) "The Impact of Communication Effectiveness and Service Quality on Relationship Commitment in Consumer Professional Services", The Journal of Services Marketing, 13, 2, pp. 151-170.

SIN, L.Y.M.; A.C.B. TSE, O.H.M. YAU, J.S.Y. LeE and R. ChOW (2002) "The Effect of Relationship Marketing Orientation on Business Performance in a Service-Oriented Economy", Journal of Services Marketing, 16, 7, pp. 656-676.

SINGH, J. and D. SIRDESHMUKH (2000) "Agency and Trust Mechanisms in Consumer Satisfaction and Loyalty Judgments", Journal of the Academy of Marketing Science, 28, 1, pp. 150-167.

SIRDESHMUKH, D.; J. SINGH and B. SABOL (2002) "Consumer Trust, Value and Loyalty in Relational Exchanges", Journal of Marketing, 66, 1, pp. 15-37.

StORBACKA, K.; T. STRANDVIK and C. GRÖNROOS (1994) "Managing Customer Relationships for Profit: the Dynamics of Relationship Quality", International Journal of Service Industry Management, 5, 5, pp. 21-38.

UlagA, W. and A. EgGeRT (2004) "Relationship Value and Relationship Quality", European Journal of Marketing, 40, 3 /4, pp. 311-327.

VeneTIS, K.A. and P.N. GhaURI (2004) "Service Quality and Customer Retention: Building Long-Term Relationships", European Journal of Marketing, 38, 11/12, pp. 1577-1598.

Walter, A.; T.A. Müller, G. Helfert and T. RitTer (2003) "Functions of Industrial Supplier Relationships and Their Impact on Relationship Quality", Industrial Marketing Management, 32, 2, pp. 159-169.

WHITE, S.S. and B. SCHNEIDER (2000) "Climbing the Commitment Ladder. The Role of Expectations on Customer's Behavior Intentions", Journal of Service Research, 2, 3, pp. 240-253.

WILSON, D.T. (1995) "An Integrated Model of Buyer-Seller Relationships", Journal of the Academy of Marketing Science, 23, 4, pp. 335-345.

WONG, A. and A. SOHAL (2002) "An Examination of the Relationship Between Trust, Commitment and Relationship Quality", International Journal of Retail \& Distribution Management, 30, 1, pp. 34-50.

Woo, K. and T. ENNEW (2004) "Business to Business Relationship Quality: an IMP Interaction Based Conceptualization and Measurement", European Journal of Marketing, 38, 9/10, pp. 1252-1271. 